\title{
Cmentarz w malarstwie i grafice Józefa Czajkowskiego
}

Streszczenie. Cmentarz to temat wręcz stworzony do snucia dekadenckich rozważań nad ulotnością i kruchością ludzkiego życia, nic zatem dziwnego, że chętnie podejmowali go młodopolscy moderniści. Jednym z nich był Józef Czajkowski (1872-1947) - twórca niezwykle wszechstronny i zasłużony dla rozwoju polskiej architektury, rzemiosła i edukacji, a przy tym grafik i malarz eksperymentujący z kompozycją, kolorem i warsztatem. Świadczy o tym litografia barwna z 1903 roku jego autorstwa, zatytułowana Cmentarz klasztorny w Krakowie, oraz obraz olejny na płótnie z 1910 roku Ogród zima, będący powtórzeniem, ale i rozwinięciem graficznej kompozycji. Czajkowski, dla którego zima ze swoim krajobrazem była ulubioną do uwieczniania porą roku (czego potwierdzeniem są dwa wybitne płótna: Sad w zimie z 1900 roku ze zbiorów Muzeum Narodowego w Krakowie oraz namalowane rok później Zima. Paw w ogrodzie z Lwowskiej Galerii Sztuki), zarówno w litografii, jak i w obrazie olejnym dał popis maestrii w syntetyzowaniu kompozycji, budowaniu przestrzeni za pomocą kontrastów walorowych i barwnych i oddawaniu atmosfery miejsca. Zwłaszcza wysmakowane niuanse w obrębie wąskiej gamy bieli, czerni i brązów, zastosowane w Ogrodzie zimą, pokazują malarską klasę Czajkowskiego, jak się okazuje - równie wybitnego pejzażystę, jak jego młodszy brat Stanisław Czajkowski. Obaj bracia byli uczniami Jana Stanisławskiego. Józef wydaje się jednak być bardziej oryginalnym i wytrawnym kolorystą i symbolistą, choć nie poświęcił się malarstwu. W swojej dojrzałej twórczości dążył do syntezy sztuk, każde dzieło traktując wielopłaszczyznowo, pod względem poszukiwań tak warsztatowych, jak i treściowych. Dlatego wątek sepulkralny, pojawiający się także w obrazie Kirkut z 1900 roku, nie wydaje się być przypadkowy i zasługuje na wnikliwą analizę - także w kontekście badań nad grafiką i malarstwem młodopolskiego modernizmu.

Słowa kluczowe: Józefa Czajkowski, malarstwo, Młoda Polska, cmentarze

ednym z oryginalniejszych pejzażystów okresu Młodej Polski był Józef Czajkowski (1872-1947), starszy brat malarza Stanisława Czajkowskiego - jednego z uczniów i kontynuatorów najlepszych tradycji polskiej szkoły pejzażu Jana Stanisławskiego. Józef również zaliczany bywa do uczniów Stanisławskiego, 
choć nie uczęszczał do słynnej katedry pejzażu mistrza, prowadzonej przez niego w Szkole Sztuk Pięknych (w 1900 roku podniesionej do godności Akademii) w Krakowie w latach 1896-1906. Uczestniczył natomiast w równie słynnych plenerach, organizowanych przez Stanisławskiego początkowo w przestrzeni miejskiej Krakowa, a następnie w podkrakowskich wsiach: Bronowicach, Rudniku, Dębnikach ${ }^{1}$. Przyszli adepci sztuki uwieczniali tamtejszy krajobraz bezpośrednio z natury, o różnych porach dnia i roku, ze szczególnym upodobaniem do momentów przesileń, takich jak zmierzchy i poranki, oraz miejsc nastrojowych, tajemniczych, niejednoznacznych. Józef był już wówczas absolwentem kilku europejskich uczelni: Akademii Sztuk Pięknych w Monachium, Académie Julian w Paryżu, Kunstgewerbeschule w Wiedniu oraz krakowskiej SSP, gdzie uzupełniał wykształcenie w roku akademickim 1894-1895, równolegle studiując architekturę na Politechnice Krakowskiej². Urodzony w Warszawie (z którą związał się zawodowo w okresie międzywojennym), reprezentował drugie pokolenie młodopolskich modernistów, związanych z elitarnym Towarzystwem Artystów Polskich „Sztuka” w Krakowie, którzy w świadomy sposób czerpali z doświadczeń impresjonizmu, symbolizmu i ekspresjonizmu, inspiracji szukali w rodzimym folklorze i kulturach pozaeuropejskich (np. w grafice japońskiej) i konsekwentnie dążyli do wypracowania polskiego stylu narodowego. Józef Czajkowski sztukę traktował całościowo i wielopłaszczyznowo, dążąc do jej syntezy pojmowanej uniwersalnie i lokalnie jednocześnie ${ }^{3}$. W historii polskiej sztuki zapisał się głównie jako wybitny reformator i projektant wnętrz, dla których projektował meble, tkaniny i witraże, a także projektant małej architektury i twórca grafiki użytkowej. Malarstwo i grafika warsztatowa jego autorstwa są dziś mniej znane, choć i na tym polu odnosił sukcesy, o czym warto przypomnieć.

Do najpopularniejszych pejzaży Czajkowskiego należą dwa muzealne obrazy, wpisujące się w kanon krajobrazu rodzimego Młodej Polski: Sad w zimie, olej na płótnie z 1900 roku ze zbiorów Muzeum Narodowego w Krakowie, oraz Zima. Paw w ogrodzie, olej na płótnie z 1901 roku, będący własnością Lwowskiej Galerii Sztuki ${ }^{4}$. Pierwszy z nich to prawdopodobnie widok Bronowic uwieczniony w ulubionej porze modernistów - scenerii zimowej, która pozwalała na wykorzystanie efektownych kontrastów walorowych w obrębie wąskich gam bieli, błękitów i czerni oraz na udramatyzowanie przedstawienia. Czajkowski dodatkowo wykorzystał tu wijącą się, secesyjną linię poskręcanych gałęzi drzew na pierwszym planie, oglądanych „po młodopolsku” - pod słońce. Nastrój drugiego płótna buduje natomiast zderzenie dostojnie kroczącego po puszystym śniegu pawia ${ }^{5}$ drugim i trzecim

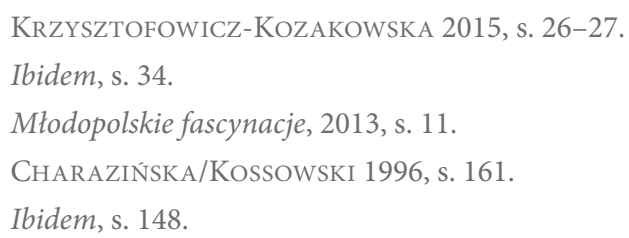


planem tonących w zapadającym zmroku, powyginanych i złowieszczych drzew. Klasę obu obrazów podbija wyrafinowany warsztat malarski: impasty i kontrasty walorowe budują przestrzeń, a zarazem odrealniają oba przedstawienia, symbolizują je, sugerując widzowi ich ukryte znaczenia. Takim dwuznacznym motywem, cenionym przez romantyków i modernistów, wskazującym zarazem na dekadencki charakter przedstawienia, jest być może paw, utożsamiany m.in. z godnością i kontemplacją, ale też ze zmartwychwstaniem i wiecznością ${ }^{6}$. Płótna są też zapowiedzią eksperymentów z kadrem, jakie pojawią się w kolejnych pejzażach Józefa. Nie bez znaczenia dla tematycznej ewolucji malarstwa Czajkowskiego wydaje się fakt jego studiów architektonicznych oraz nauki w pracowni Tadeusza Stryjeńskiego ${ }^{7}$, krakowskiego architekta tworzącego w stylu secesji, konserwatora zabytków i przedsiębiorcy budowlanego, z którym Józef będzie opracowywał projekty tzw. Wielkiego Krakowa w 1910 roku. Od 1906 roku sam zaczął projektować w dziedzinie architektury i architektura pojawia się również w jego malarstwie, czego ciekawym przykładem jest Dwór zima z ok. 1905 roku $^{8}$ - kolejny postimpresjonistyczny pejzaż zimowy ukazujący spectrum warsztatowych możliwości autora. Tytułowy polski dwór szlachecki wyłania się zza szpaleru drzew rzucających efektowne cienie na skąpanym w słońcu śniegu na pierwszym planie. Warto zwrócić uwagę także na sposób kadrowania, coraz bardziej syntetyczny, nieunikający płaskości i zabawy z perspektywą - co pogłębia dematerializację obrazu. Młodopolskim pejzażystom nie chodziło bowiem o realizm przedstawianych miejsc, krajobraz był raczej pretekstem do rozważań egzystencjalnych, oddawania stanów duszy, niepokojów i refleksji nachodzących ludzi fin de siècle'u - obserwujących koniec pewnej epoki ale i narodziny nowoczesności. Należy w tym miejscu nadmienić, że Czajkowski w swoich projektach architektonicznych był propagatorem tzw. stylu dworkowego, który pojawił się w polskim budownictwie po I wojnie światowej. Punktem odniesienia dla wznoszonych w tej stylistyce obiektów, zarówno prywatnych willi i kamienic, jak i gmachów użyteczności publicznej typu dworce czy urzędy, był staropolski alkierzowy dwór szlachecki z jego symetryczną kompozycją, wysokim i łamanym dachem, oraz uproszczone formy klasyczne $\mathrm{z}$ charakterystycznym portykiem kolumnowym zwieńczonym trójkątnym frontonem poprzedzającym wejście.

Po odzyskaniu niepodległości w 1918 roku polscy architekci kontynuowali poszukiwania stylu narodowego, będącego wyrazem ambicji i silnego poczucia własnej wartości mieszkańców odrodzonej Rzeczypospolitej’. Należał do nich także Józef Czajkowski, członek-organizator stowarzyszeń Towarzystwo Polska Sztuka Stosowana, Warsztaty Krakowskie i Kilim Polski, który inspiracji szukał w sztuce

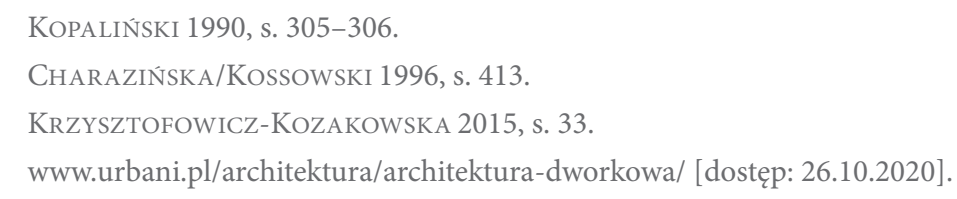




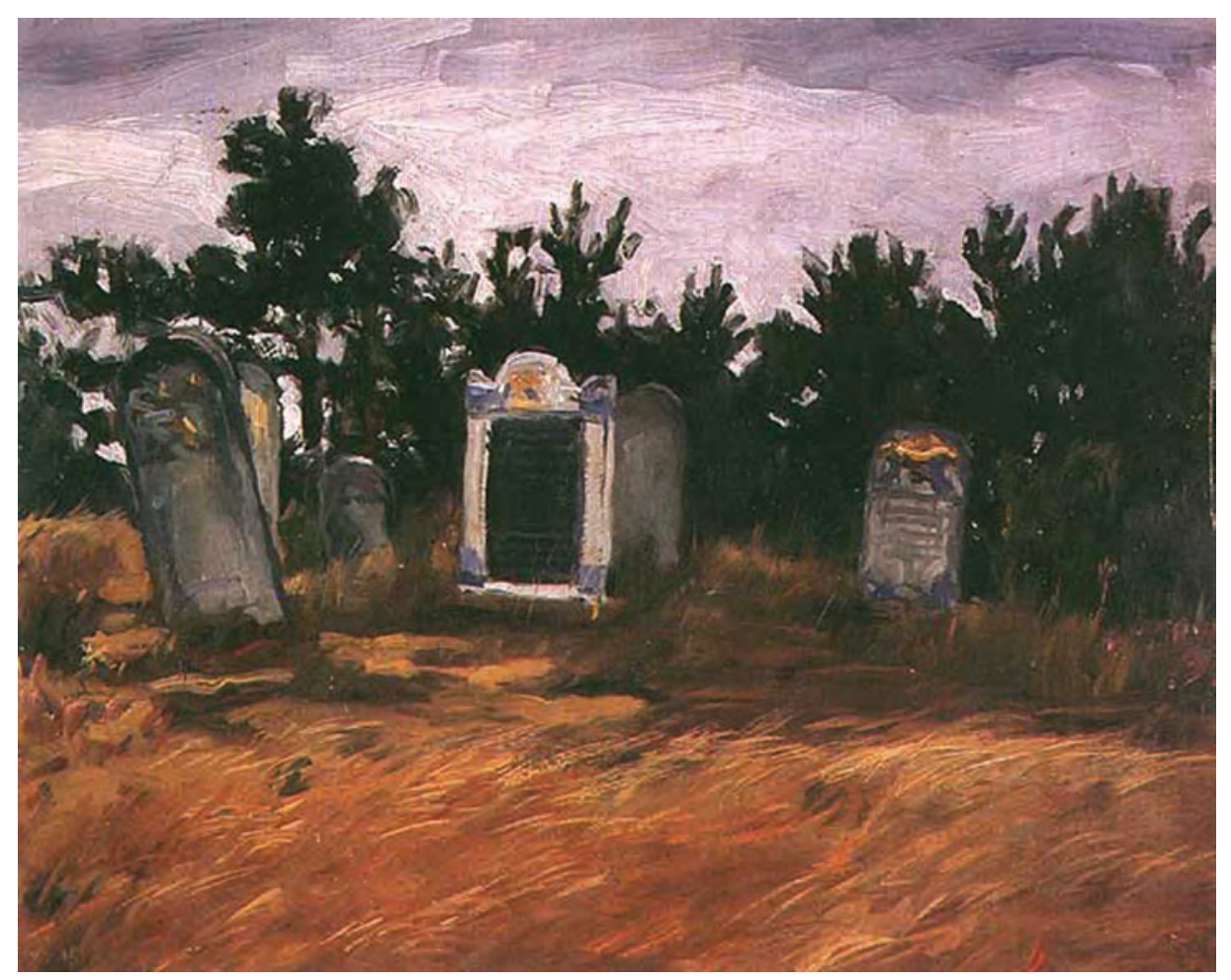

1. Józef Czajkowski, Kirkut, 1900, olej na desce 32,2 × 40 cm. Kolekcja prywatna. Wg http://artyzm.com/ obraz.php?id=7883 (domena publiczna)

ludowej Podhala, poddając jej formy stylizacji i geometryzacji. Największym jego sukcesem (do tego ponadlokalnym), polegającym na twórczym połączeniu rodzimych tradycji z nowoczesnością, był bodajże Pawilon Polski zaprezentowany na Międzynarodowej Wystawie Sztuk Dekoracyjnych w Paryżu w 1925 roku. Zarówno jego pełna ekspresji, a przy tym elegancka forma zewnętrzna, jak i wystrój wnętrz były wielkim triumfem polskiej sztuki stosowanej i przyniosły Grand Prix całemu zespołowi naszych projektantów, pedagogów Szkoły Sztuk Pięknych w Warszawie, w skład którego oprócz Czajkowskiego wchodzili Karol Stryjeński, Henryk Kuna, Wojciech Jastrzębowski, Jan Szczepkowski, Władysław Skoczylas i Jerzy Gwalbert ${ }^{10}$.

Powróćmy jednak do malarskich sukcesów Józefa. Tematem wręcz stworzonym do snucia dekadenckich refleksji na przełomie XIX i XX wieku był cmentarz, intrygujący artystów jako miejsce szczególnej zadumy nad ulotnością i marnością ludzkiego życia, przestrzeń łącząca sacrum i profanum, duchowość i doczesność. W obrazach Czajkowskiego cmentarz pojawia się we wczesnym malarstwie, czego przykładem jest Kirkut z 1900 roku, olej na desce z kolekcji prywatnej ${ }^{11}$.

$10 \quad$ Sztuka wszędzie, 2012, s. 167-171.

11 www.sztuka.agraart.pl/licytacja/17/1005 [dostęp: 26.10.2020]. 




2. Józef Czajkowski, Cmentarz klasztorny w Krakowie, 1903, litografia barwna na papierze 52 × 35 cm. Fot. dzięki uprzejmości Sopockiego Domu Aukcyjnego

Tym razem artysta jako porę roku wybrał lato, umieszczając pojedyncze żydowskie nagrobki w spłowiałej od słońca, żółtej, ekspresyjnie falującej trawie. Kompozycję zamyka zaś ciemna linia drzew na horyzoncie. Nie wiemy, czy to jeden z licznych kirkutów w ówczesnej Galicji, czy też suma wyobrażeń autora o cmentarzu. Tego typu kompozycji Czajkowski wykonał więcej, wystawiał je w Towarzystwie Przyjaciół Sztuk Pięknych w Krakowie do 1904 roku, co świadczy o jego zainteresowaniu tą tematyką. Nekropolia, jako pretekst do eksperymentów formalnych, pojawi się także w widokach Krakowa, którego zabytkową architekturę Józef uwieczniał $\mathrm{w}$ różnych okresach swojej malarskiej aktywności, także w międzywojniu, kiedy już mieszkał i pracował w Warszawie. Przykładem tego jest motyw kameralnego cmentarza miejskiego przy krakowskim kościele ojców reformatów, 


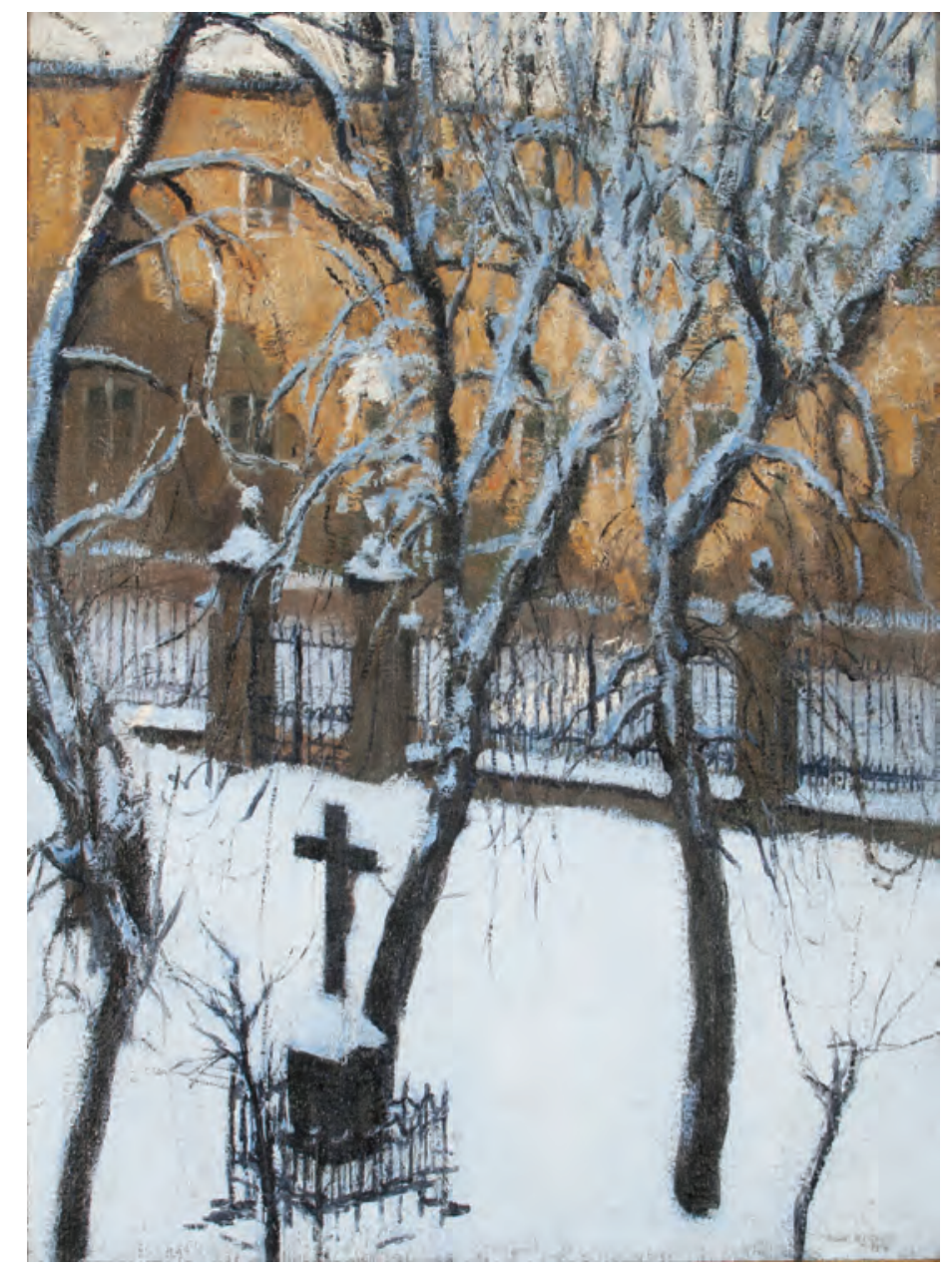

3. Józef Czajkowski, Ogród zimą, ok. 1906, olej na płótnie 96 × 70,5cm. Kolekcja prywatna

pojawiający się najpierw w litografii barwnej, a następnie w obrazie olejnym Czajkowskiego z okresu młodopolskiego.

Niewielki kościół ojców reformatów wraz z zabudowaniami klasztornymi został wzniesiony w Krakowie po potopie szwedzkim, tuż przy miejskich murach, jako sanktuarium świętego Kazimierza Królewicza - historycznego patrona Polski. Parcela po przeciwnej stronie ulicy Reformackiej została przekazana zakonowi w 1735 roku i była użytkowana jako cmentarz. Mur oddzielający ten teren od ulicy został wzniesiony w 1863 roku. Dzisiaj pozostały tutaj stacje drogi krzyżowej w formie kapliczek z głębokimi wnękami na obrazy ${ }^{12}$. Jak to miejsce wyglądało na początku

\footnotetext{
12 www.krakow-przewodnik.com.pl/krakowskie-zabytki/kosciol-reformatow-pw-sw-kazimierza/ [dostęp: 20.10.2020].
} 
XX wieku, dowiemy się z prac Józefa Czajkowskiego. W 1903 roku, na potrzeby Teki Stowarzyszenia Polskich [Artystów] Grafików, wydanej w Zakładzie litograficznym A. Pruszyńskiego w Krakowie, artysta przygotował barwną litografię o wymiarach $52 \times 35 \mathrm{~cm}$, zatytułowaną Cmentarz klasztorny w Krakowie ${ }^{13}$. Na uwagę zwraca sposób wykadrowania tego miejskiego widoku: cmentarna furta, za którą widać uliczkę i położony po drugiej stronie budynek klasztorny, oglądana jest z wysokiej perspektywy, przez pryzmat bezlistnego drzewa na pierwszym planie i otoczonego palikowym ogrodzeniem samotnego nagrobka z czarnym krzyżem. Wszystko zatopione jest zaś w głębokim śniegu, którego biel, wraz z czernią, brązami i ugrami, zamyka wąską gamę barwną tej grafiki. Widać tu syntetyzowanie bliskie estetyce japońskiej - każdy plan i szczegół jest równoważny, autor nie narzuca widzowi żadnej perspektywy, celowo spłaszczając kompozycję. Zwraca uwagę także brak słońca, niewykluczający wszakże kontrastów walorowych, za pomocą których artysta oddaje bryłowatość architektury. Całość spowija zaś senna zimowa cisza, budująca nastrój skupienia i melancholii, tak właściwy nekropoliom. Litografia ta, a właściwie autolitografia barwna podmalowana kredką i pędzlem na papierze japońskim, wzbudzać musiała zainteresowanie współczesnych, gdyż na rynku sztuki po dziś dzień funkcjonują jej późniejsze odbitki, np. z 1907 roku ${ }^{14}$ - tego samego formatu, datowane i sygnowane imieniem i nazwiskiem autora w lewym dolnym rogu.

Widok przyklasztornego cmentarza ojców reformatów w Krakowie musiał jednak nadal intrygować wyobraźnię Józefa, gdyż kilka lat po litografii powstaje obraz olejny zatytułowany Ogród zimą, będący powtórzeniem graficznej kompozycji, choć bardziej rozbudowanej o partię drzew przysłaniających gmach wyłaniający się $\mathrm{w}$ tle. Scena również rozgrywa się w pionie, co dynamizuje przedstawienie, oglądane z wysokiej perspektywy, wręcz z lotu ptaka. Na pierwszym planie, jakby nieco przesuniętym $\mathrm{w}$ lewą stronę $\mathrm{w}$ stosunku do grafiki, znajduje się ten sam samotny nagrobek z krzyżem w otoczeniu przysypanych śniegiem drzew. Śnieg zalega także na ogrodzeniu i furcie, a jego nieskazitelna biel daje poczucie lekkości i, podobnie jak w litografii, syntetyzuje i wypłaszcza perspektywę, w jakiś sposób monumentalizując to kameralne przedstawienie. Tym razem jednak pojawia się akcent słoneczny, widoczny w malowniczo układających się światłocieniach na fasadzie budynku widocznego zza drzew - artysta wykazał się tu prawdziwą maestrią w konstruowaniu subtelnych przejść walorowych w gamie ciepłych ugrów i brązów skontrastowanych z chłodnymi bielami i czerniami pierwszego planu. Po raz kolejny udowodnił też, że z surowego zimowego krajobrazu można wydobyć szereg niuansów i smaków zdradzających wyrafinowanego kolorystę i wytrawnego pejzażystę nieobawiającego się odważnego eksperymentowania z kadrem (warto zwrócić uwagę na ekspresyjną plątaninę gałęzi i wygięcia pni drzew) i przestrzenią.

\footnotetext{
Zawsze Młoda! 2012, s. 192.

14 www.artinfo.pl/artysci/jozef-czajkowski/archiwum [dostęp: 26.10.2020].
} 


\section{TECHNE \\ T E X N H \\ SERIA NOWA

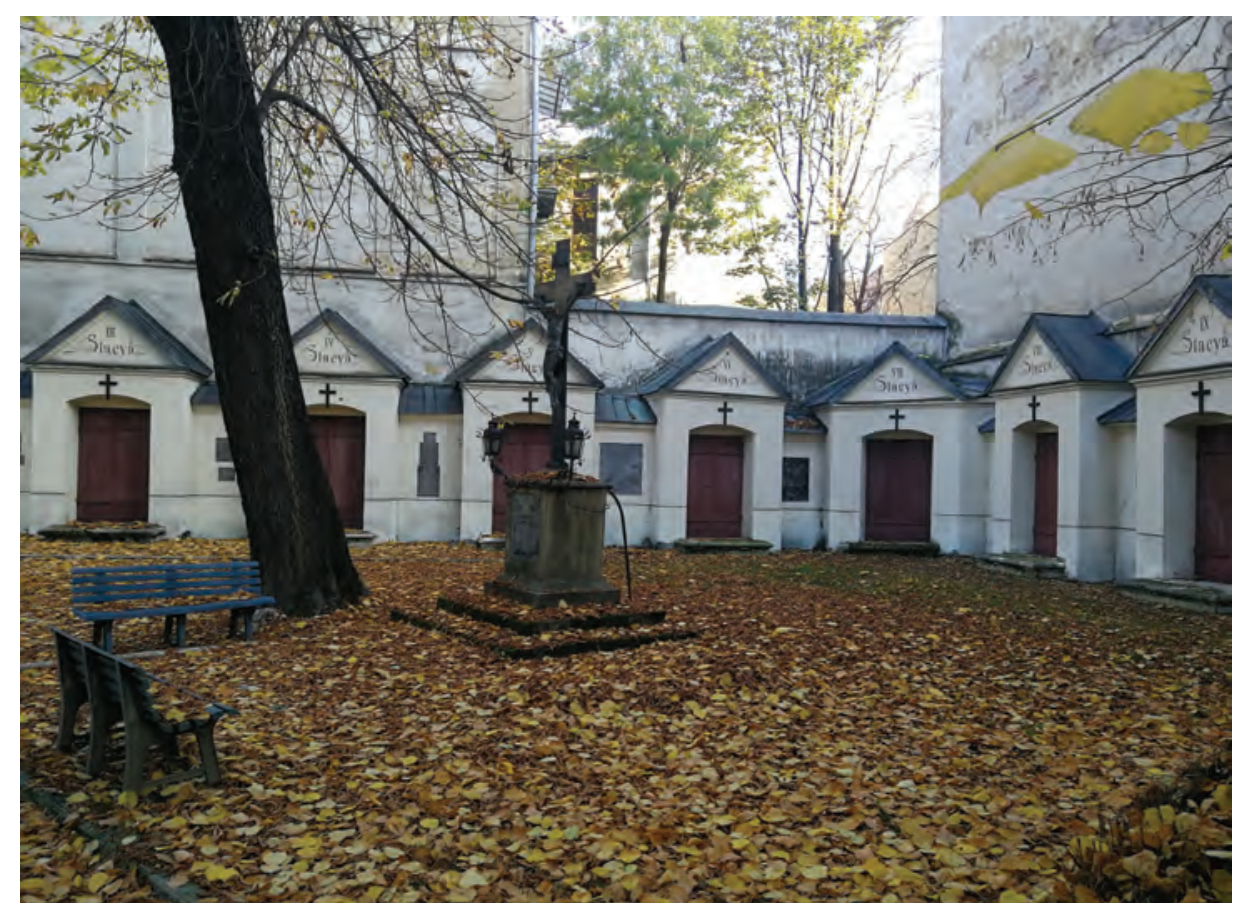

4. Teren dawnego cmentarza współcześnie. Fot. Tomasz Zjawiony

Czy ten efektowny kolorystycznie i warsztatowo obraz rozpatrywać należy jako wyraz fascynacji autora sepulkralną architekturą Krakowa, czy raczej jako przykład pejzażu symbolicznego, oddającego egzystencjalne rozterki młodopolskiej duszy? Odpowiedź leży zapewne pośrodku, choć właściciel tego dzieła, łódzki kolekcjoner, nabył je, aby poszerzyć swoją imponującą kolekcję malarstwa z okresu Młodej Polski, jego ulubionej epoki w dziejach polskiej sztuki. Obok opisywanego tu Ogrodu zima z 1910 roku, oleju na płótnie o wymiarach $96 \times 70,5 \mathrm{~cm}$, znajduje się w niej jeszcze nostalgiczny Pejzaż letni pędzla Józefa Czajkowskiego - niedatowany olej na tekturze, zapewne również z początku XX wieku ${ }^{15}$. Wraz z obrazami takich mistrzów jak Olga Boznańska, Józef Chełmoński, Julian Fałat, Jacek Malczewski, Jan Stanisławski czy Leon Wyczółkowski wpisują się one w najlepsze tradycje polskiego malarstwa nowoczesnego, będąc zarazem potwierdzeniem wszechstronności talentów Józefa Czajkowskiego - wybitnego projektanta i pedagoga, ale też grafika i malarza.

15 Młodopolskie fascynacje, 2013, s. 11. 


\section{Bibliografia}

\section{Opracowania}

CHARAZIŃsKa/Kossowski 1996 - Elżbieta Charazińska, Łukasz Kossowski, Koniec wieku. Sztuka polskiego modernizmu 1890-1914, kat. wystawy, Muzeum Narodowe w Warszawie, Warszawa 1996.

KOPALIŃSKi 1990 - Władysław Kopaliński, Słownik symboli, Warszawa 1990.

Krzysztofowicz-Kozakowska 2015 - Stefania Krzysztofowicz-Kozakowska, Jan Stanisławski i jego uczniowie, Ożarów Mazowiecki 2015.

Młodopolskie fascynacje 2013 - Młodopolskie fascynacje. Malarstwo końca XIX i pierwszej połowy XX wieku z kolekcji prywatnej, red. M. Nowakowska, Katalog wystawy w Muzeum Miasta Łodzi, Łódź 2013.

Sztuka wszędzie 2012 - Sztuka wszędzie. Akademia Sztuk Pięknych w Warszawie 1904-1944, red. M. Sitkowska, Warszawa 2012.

Zawsze Młoda! 2012 - Zawsze Młoda! Polska sztuka około 1900 roku, red. K. Kulig-Janarek, Katalog wystawy w Muzeum Narodowym w Krakowie, Kraków 2012.

\section{Netografia}

http://krakow-przewodnik.com.pl/krakowskie-zabytki/kosciol-reformatow-pw-sw-kazimierza/ [dostęp: 20.10.2020].

https://artinfo.pl/artysci/jozef-czajkowski/archiwum [dostęp: 26.10.2020].

https://sztuka.agraart.pl/licytacja/17/1005 [dostęp: 26.10.2020].

https://urbani.pl/architektura/architektura-dworkowa/ [dostęp: 26.10.2020]. 


\section{The cemetery theme in paintings and graphics by Józef Czajkowski}

$\mathrm{T}$

he cemetery is a topic seemingly created to weave decadent reflections on the ephemerality and fragility of human life, so it is no wonder that it was eagerly taken up by Young Poland modernists. One of them was Józef Czajkowski (1872-1947) - an extremely versatile artist who contributed to the development of Polish architecture, craftsmanship and education, as well as an experimental graphic artist and painter. This is evidenced by the color lithograph from 1903, "Monastery Cemetery in Krakow" and the oil painting on canvas from 1910, "Winter Garden", which is an extension of the graphic composition. Both in lithography and in an oil painting, Czajkowski showed his mastery in synthesizing a composition, building space and conveying the atmosphere of a place. Especially the tasteful nuances within the narrow range of white, black and brown, used in "Winter Garden", show Czajkowski's painterly class, as it turns out - a landscape's painter as outstanding as his younger brother Stanisław Czajkowski. Both brothers were students of Jan Stanisławski. Although, Józef seems to be a more original and consummate colorist and symbolist, he has not devoted himself to painting. In his mature work, he strove to synthesize the arts, both in terms of workshop and content. That is why the sepulchral theme, appearing also in the 1900 painting "Kirkut", does not seem to be accidental and deserves a thorough analysis - also in the context of research on graphics and painting of Young Poland's modernism.

Keywords: Józef Czajkowski, painting, Young Poland, modernism, cemetaries 